\title{
Anabolic Effect of $\beta$-Cryptoxanthin on Bone Components in the Femoral Tissues of Aged Rats in Vivo and in Vitro
}

\author{
Satoshi Uchiyama, ${ }^{a}$ Takashi Sumida, ${ }^{b}$ and Masayoshi Yamaguchi*, $a$ \\ ${ }^{a}$ Laboratory of Endocrinology and Molecular Metabolism, Graduate School of Nutritional Sciences, University of Shizuoka, 52-1 Yada, \\ Shizuoka 422-8526, Japan and ${ }^{b}$ Research \& Development, Ehime Beverage Inc., 478 Anjyoji-machi, Matsuyama 791-8603, Japan
}

(Received May 21, 2004; Accepted June 7, 2004)

\begin{abstract}
The effect of $\beta$-cryptoxanthin on bone components in the femoral tissues of aged rats was investigated. $\beta$ Cryptoxanthin was isolated from Satsuma mandarin (Citrus unshiu MARC.). $\beta$-Cryptoxanthin (5, 10 , or $20 \mu \mathrm{g} / 100 \mathrm{~g}$ body weight) was orally administered once daily for 7 days to aged (50 week old) female rats. The administration of $\beta$-cryptoxanthin (10 or $20 \mu \mathrm{g} / 100 \mathrm{~g}$ body weight) caused a significant increase in calcium content, alkaline phosphatase activity and deoxyribonucleic acid (DNA) content in the femoral-diaphyseal and -metaphyseal tissues. Femoral-diaphyseal calcium content and alkaline phosphatase activity were significantly increased by the dose of $5 \mu \mathrm{g} /$ $100 \mathrm{~g}$ body weight. A significant increase in metaphyseal alkaline phosphatase activity was also seen with the dose of $5 \mu \mathrm{g} \beta$-cryptoxanthin/100 g body weight. Moreover, bone tissues were cultured for $48 \mathrm{hr}$ in serum-free Dulbecco's modified Eagle's medium containing either vehicle or $\beta$-cryptoxanthin $\left(10^{-7}\right.$ or $\left.10^{-6} \mathrm{M}\right)$. The presence of $\beta$-cryptoxanthin $\left(10^{-7}\right.$ or $\left.10^{-6} \mathrm{M}\right)$ caused a significant increase in calcium content and alkaline phosphatase activity in the femoral-diaphyseal and -metaphyseal tissues obtained from aged (50 week old) female rats. These increases were completely abolished in the presence of cycloheximide $\left(10^{-6} \mathrm{M}\right)$, an inhibitor of protein synthesis. This study demonstrated that $\beta$-cryptoxanthin has an anabolic effect on bone components in aged female rats in vivo and in vitro.
\end{abstract}

Key words $-\beta$-cryptoxanthin, bone formation, osteoporosis, aged rat femur

\section{INTRODUCTION}

Aging induces a decrease in bone mass, ${ }^{1,2)}$ and osteoporosis with its accompanying decrease in bone mass is widely recognized as a major public health problem. The most dramatic expression of the disease is represented by fractures of the proximal femurs. ${ }^{3)}$ Bone loss with increasing age may be due to decreased bone formation and increased bone resorption. Pharmacological and nutritional factors may prevent bone loss with aging. ${ }^{4}$ We investigate the anabolic effect of various food factors on bone metabolism in preventing osteoporosis. ${ }^{5-10)}$ Chemical compounds in food that act on bone metabolism, however, are poorly understood.

The anticarcinogenic effects of various micronutrients and phytochemicals found in vegetables

\footnotetext{
*To whom correspondence should be addressed: Laboratory of Endocrinology and Molecular Metabolism, Graduate School of Nutritional Sciences, University of Shizuoka, 52-1 Yada, Shizuoka 422-8526, Japan. Tel. \& Fax: +81-54-264-5580; Email: yamaguch@u-shizuoka-ken.ac.jp
}

and fruits, such as carotenoids, have been demonstrated in laboratory studies. ${ }^{11)}$ Carotenoids have been shown to play a possible biological role in cancer prevention. ${ }^{11)}$ This preventive effect on osteoporosis, however, has not been fully clarified. Vitamin A is known to have a detrimental effect on bone at high doses. High levels of vitamin A lead to accelerated bone resorption, bone fractures, and osteoporotic bone lesions in animals. ${ }^{12-14)}$

$\beta$-Cryptoxanthin is a carotenoid abundant in Satsuma mandarin (Citrus unshiu MARC.), and it is enzymatically converted from $\beta$-carotene (provita$\min \mathrm{A}$ ) in plants. Of the various carotenoids (including $\beta$-cryptoxanthin, lutein, lycopene, and $\beta$-carotene) and rutin (quercetin-3-rutinoside), $\beta$-cryptoxanthin has been found to have a unique anabolic effect on bone calcification. ${ }^{15)}$ It has a stimulatory effect on bone formation and an inhibitory effect on bone resorption in rat femoral tissue culture in vitro. ${ }^{16)}$ Moreover, $\beta$-cryptoxanthin inhibits osteoclast-like cell formation induced by bone-resorbing factors in mouse marrow cultures in vitro, ${ }^{17)}$ suggesting that it inhibits osteoclastic bone resorption. 
A decrease in bone components in the femoral tissues is found in aged rats. ${ }^{18)}$ This study, therefore, was undertaken to determine whether $\beta$-cryptoxanthin has an anabolic effect on these components in aged rats in vivo. We found that oral administration of the substance does induce this effect on the femoral tissues.

\section{MATERIALS AND METHODS}

\section{Chemicals — Dulbecco's modified Eagle's me-} dium (DMEM) (high glucose, $4.5 \mathrm{~g} / \mathrm{dl}$ ) and a penicillin-streptomycin solution (5000 units/mg penicillin and $5000 \mu \mathrm{g} / \mathrm{ml}$ streptomycin) were obtained from Gibco Laboratories (Grand Island, NY, U.S.A.). Bovine serum albumin (BSA), cycloheximide, and corn oil were obtained from Sigma Chemical (St. Louis, MO, U.S.A.). $\beta$-Cryptoxanthin (100\% purity) was supplied by Ehime Beverage Inc. (Matsuyama, Japan). All other chemicals were reagent grade from Wako Pure Chemical Industries (Osaka, Japan). All water used was glass-distilled.

Animals — Female Wistar rats (50 weeks old) were obtained from Japan SLC (Hamamatsu, Japan). The animals were fed commercial laboratory chow (solid) containing $57.4 \% \mathrm{Ca}$ and $1.1 \% \mathrm{P}$ for 7 days at a room temperature of $25^{\circ} \mathrm{C}$ and had free access to distilled water.

\section{Administration Procedures $-\beta$-Crytoxanthin} was dissolved in corn oil at a concentration of $(5$, 10 , or $20 \mu \mathrm{g} / \mathrm{ml} / 100 \mathrm{~g}$ body weight) and orally administered to rats through a stomach tube once daily for 7 days. Control rats received corn oil $(1 \mathrm{ml} / 100 \mathrm{~g}$ body weight) orally. The animals were killed $24 \mathrm{hr}$ after the last administration by cardiac puncture under light ether anesthesia, and the blood and femur were removed immediately.

Bone Culture —— The femurs, which were obtained from aged (50 week old) female rats, were removed aseptically after exsanguinations and soaked in ice-cold $0.25 \mathrm{M}$ sucrose solution. The femur was cleaned of soft tissue and marrow, and the diaphysis and metaphysis (not containing epiphyseal tissue) were separated. The femoral-diaphyseal and -metaphyseal tissues were cut into small pieces. Femoral-diaphyseal or -metaphyseal fragments were cultured for $48 \mathrm{hr}$ in $35-\mathrm{mm}$ dishes in $2.0 \mathrm{ml}$ of medium consisting of DMEM (high glucose, $4.5 \mathrm{~g} / \mathrm{dl}$ supplemented with $0.25 \%$ BSA) plus antibiotics (100 units of penicillin and $100 \mu \mathrm{g}$ of streptomycin/ $\mathrm{ml}$ medium) ${ }^{19)}$ In the experiments, bone tissue was cultured for $48 \mathrm{hr}$ in a medium containing either vehicle or compound (including $0.1 \%$ ethanol). Cultures were maintained at $37^{\circ} \mathrm{C}$ in a water-saturated atmosphere containing $5 \% \mathrm{CO}_{2}$ and $95 \%$ air.

Analytical Procedures — Blood samples were centrifuged for $30 \mathrm{~min}$ after collection, and the serum was separated. Serum calcium levels were was determined using the method of Willis. ${ }^{20)}$ Serum inorganic phosphorus levels were measured using the method of Taussky and Shon. ${ }^{21)}$

The diaphyseal and metaphyseal tissues were dried for $16 \mathrm{hr}$ at $110^{\circ} \mathrm{C}$. Calcium content was determined by atomic absorption spectrophotometry. ${ }^{21)}$ Calcium content in bone tissues is expressed as milligrams/gram of dry bone.

To assay alkaline phosphatase activity, the diaphyseal and metaphyseal tissues were immersed in $3.0 \mathrm{ml}$ of ice-cold $6.5 \mathrm{mM}$ barbital buffer (pH 7.4), cut into small pieces, homogenized with a physcotron homogenizer, and disrupted for $60 \mathrm{sec}$ with an ultrasonic device. The supernatant centrifuged at $600 \times g$ for $5 \mathrm{~min}$ was used to measure enzyme activity. Enzyme assay was carried out under optimal conditions. Alkaline phosphatase activity was determined using the method of Walter and Schutt. ${ }^{22)}$ Enzyme activity was expressed as $\mu$ mol of p-nitrophenol liberated/minute/milligram of protein. Protein concentration was determined using the method of Lowry et al. ${ }^{23)}$

To measure bone DNA content, the diaphyseal and metaphyseal tissues were shaken with $4.0 \mathrm{ml}$ of ice-cold $0.1 \mathrm{M} \mathrm{NaOH}$ solution for 24 after homogenization of the bone tissues. ${ }^{24)}$ After alkali extraction, the samples were centrifuged at $10000 \times g$ for $5 \mathrm{~min}$, and the supernatant was collected. DNA content in the supernatant was determined using the method of Ceriotti. ${ }^{25)}$ and expressed as the amount of DNA (mg)/g wet weight of bone tissue.

Statistical Analysis — The significance of difference between values was estimated using Student's $t$-test. $p$-Values of less than 0.05 were considered to indicate statistically significant differences.

\section{RESULTS}

\section{Effect of Administration of $\beta$-Cryptoxanthin on Bone Component in Aged Rats in Vivo}

The body weight of aged female rats was not significantly altered by the oral administration of $\beta$ cryptoxanthin $(5,10$, or $20 \mu \mathrm{g} / 100 \mathrm{~g}$ body weight $)$ 
Table 1. Body Weight and Serum Components in Aged Female Rats Orally Administered $\beta$-Cryptoxanthin

\begin{tabular}{cccc}
\hline \hline Dose & Body weight & \multicolumn{2}{c}{ Serum concentration $(\mathrm{mg} / \mathrm{dl})$} \\
\cline { 3 - 4 }$(\mu \mathrm{g} / 100 \mathrm{~g}$ body weight $)$ & $(\mathrm{g})$ & Calcium & Inorganic phosphorus \\
\hline Control & $253.0 \pm 5.9$ & $9.52 \pm 0.69$ & $5.02 \pm 0.19$ \\
5 & $251.0 \pm 3.3$ & $9.12 \pm 0.16$ & $5.51 \pm 0.34$ \\
10 & $252.2 \pm 1.7$ & $8.59 \pm 0.13$ & $4.53 \pm 0.13$ \\
20 & $248.6 \pm 9.8$ & $5.27 \pm 0.22$ \\
\hline
\end{tabular}

Rats were orally administered $\beta$-cryptoxanthin $(5,10$, or $20 \mu \mathrm{g} / 100 \mathrm{~g}$ body weight) once daily for 7 days. Each value is the mean \pm S.E.M. of six rats. Data were not significant as compared with the control value.

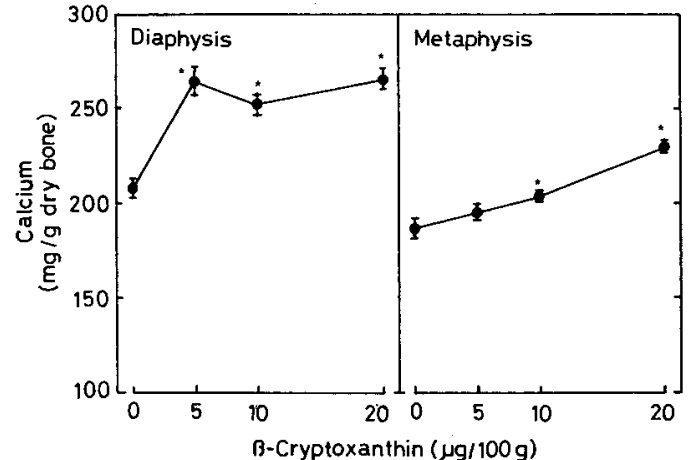

Fig. 1. Effect of Administration of $\beta$-Cryptoxanthin on Calcium Content in Femoral-Diaphyseal and -Metaphyseal Tissues of Aged Rats in Vivo

$\beta$-Cryptoxanthin $(5,10$, or $20 \mu \mathrm{g} / 100 \mathrm{~g}$ body weight) was orally administered once daily for 7 days to rats. Each value is the mean \pm S.E.M. of six rats. $* p<0.01$ compared with the control (vehicle) value.

for 7 days (Table 1). Serum calcium and inorganic phosphorus concentrations were also not significantly changed by such administration (Table 1 ). This oral administration did, however, cause a significant increase in calcium content in the femoraldiaphyseal tissues (Fig. 1), and the increase in metaphyseal calcium content was particularly significant with the dose of 10 or $20 \mu \mathrm{g} / 100 \mathrm{~g}$ body weight.

Alkaline phosphatase activity in the femoral-diaphyseal and -metaphyseal tissues was significantly increased by the oral administration of $\beta$ cryptoxxanthin $(5,10$, or $20 \mu \mathrm{g} / 100 \mathrm{~g}$ body weight $)$ to aged female rats for 7 days (Fig. 2), and 10 or $20 \mu \mathrm{g} / 100 \mathrm{~g}$ body weight for the same period also significantly raised DNA content (Fig. 3).

\section{Effect of $\beta$-Cryptoxanthin on Bone Components in Tissue Culture in Vitro}

Femoral-diaphyseal and -metaphyseal tissues obtained from aged female rats were cultured for $48 \mathrm{hr}$ in a medium containing either vehicle or $\beta$ cryptoxanthin $\left(10^{-7}\right.$ or $\left.10^{-6} \mathrm{M}\right)$ in the presence or ab-

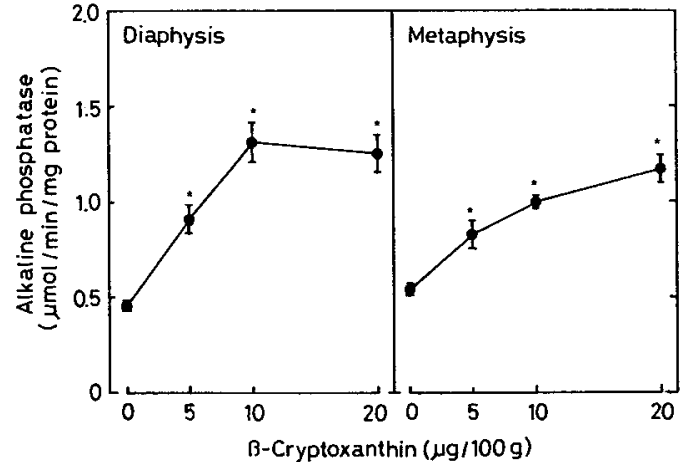

Fig. 2. Effect of Administration of $\beta$-Cryptoxanthin on Alkaline Phosphatase Activity in Femoral-Diaphyseal and -Metaphyseal Tissues of Aged Female Rats in Vivo

$\beta$-Cryptoxanthin $(5,10$, or $20 \mu \mathrm{g} / 100 \mathrm{~g}$ body weight) was orally administered once daily for 7 days to rats. Each value is the mean \pm S.E.M. of six rats. $* p<0.01$ compared with the control (vehicle) value.

sence of cycloheximide $\left(10^{-6} \mathrm{M}\right)$. The presence of $\beta$-cryptoxanthin $\left(10^{-7}\right.$ or $\left.10^{-6} \mathrm{M}\right)$ caused a significant increase in calcium content (Fig. 4) and alkaline phosphatase activity (Fig. 5) in these tissues. These increases were completely prevented in the presence of cycloheximide $\left(10^{-6} \mathrm{M}\right)$, an inhibitor of protein synthesis.

\section{DISCUSSION}

Previous studies showed that synthetic $\beta$-cryptoxanthin has a unique anabolic effect on bone formation and bone calcification in vitro, ${ }^{15)}$ and the compound has been shown to have an inhibitory effect on osteoclastic bone resorption induced by various bone-resorbing factors in vitro. ${ }^{16,17)} \beta$-Cryptoxanthin may have a stimulatory effect on bone mass, and it may also have a preventive effect on bone loss.

Bone components are decreased with age. ${ }^{18)}$ The oral administration of $\beta$-cryptoxanthin to aged female rats for 7 days was found to induce an ana- 


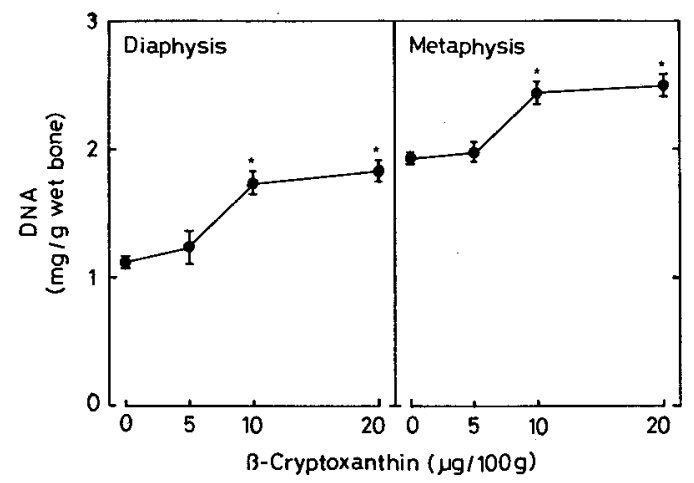

Fig. 3. Effect of Administration of $\beta$-Crytoxanthin on DNA in Femoral-Diaphyseal and -Metaphyseal Tissues of Aged Female Rats in Vivo

$\beta$-Crytoxanthin $(5,10$, or $20 \mu \mathrm{g} / 100 \mathrm{~g}$ body weight) was orally administered once daily for 7 days to rats. Each value is the mean \pm S.E.M. of six rats. ${ }^{*} p<0.01$ compared with the control (vehicle) value.

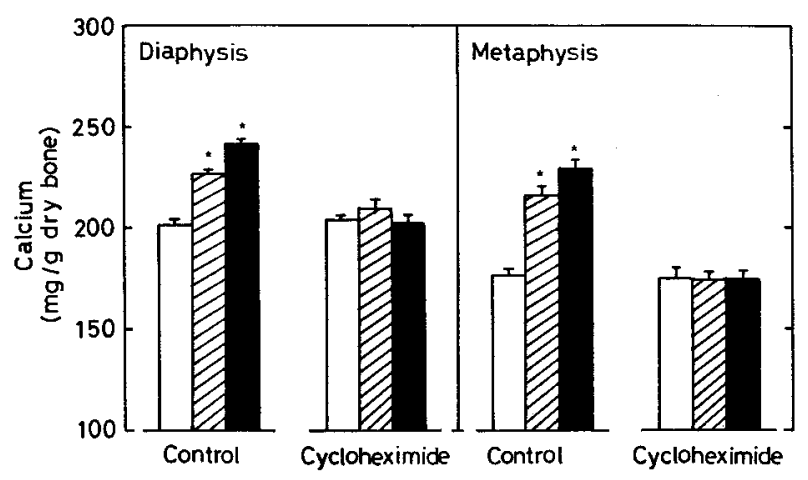

Fig. 4. Effect of Administration of $\beta$-Cryptoxanthin on Calcium Content in Femoral-Diaphyseal and -Metaphyseal Tissues obtained from Aged Female Rats in Vitro

Bone tissues were cultured for $48 \mathrm{hr}$ in a serum-free medium containing either vehicle of $\beta$-cryptoxanthin $\left(10^{-7}\right.$ or $\left.10^{-6} \mathrm{M}\right)$ in the presence or absence of cycloheximide $\left(10^{-6} \mathrm{M}\right)$. Each value represents the mean \pm S.E.M. of five experiments with separate rats. $* p<0.01$ compared with the control (none) value. White bars, control (vehicle); hatched bars, $\beta$-crytoxanthin $\left(10^{-7} \mathrm{M}\right)$; black bars, $\beta$-crytoxanthin $\left(10^{-6} \mathrm{M}\right)$.

bolic effect on bone components in vivo. Its administration caused a significant increase in calcium content, alkaline phosphatase activity, and DNA content in the femoral-diaphyseal (cortical bone) and -metaphyseal (trabecular bone) tissues of aged rats. Alkaline phosphatase is an enzyme maker of osteoblasts, and the enzyme participates in bone mineralization. ${ }^{26)}$ DNA content in bone tissues is an index of the number of bone cells. ${ }^{27)}$ The administration of $\beta$-cryptoxanthin may have a stimulatory effect on osteoblastic bone formation in the femoral tissues of aged female rats in vivo. Its anabolic effect was

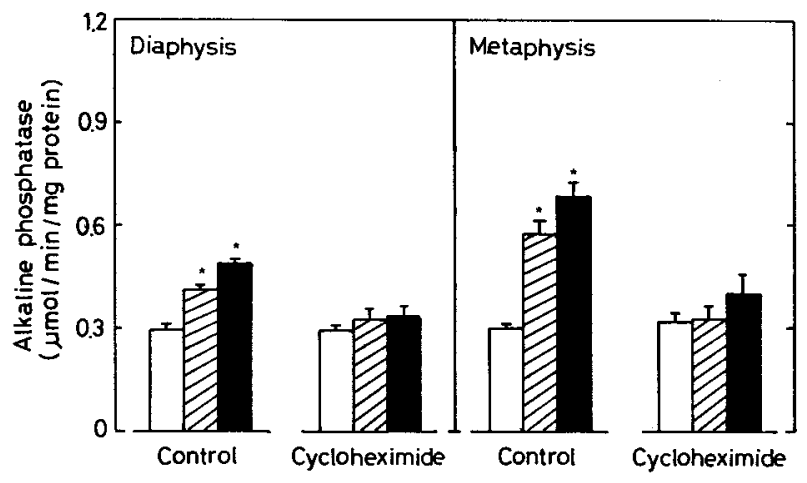

Fig. 5. Effect of Administration of $\beta$-Cryptoxanthin on Alkaline Phosphatase Activity in Femoral-Diaphyseal and -Metaphyseal Tissues obtained from Aged Female Rats in Vitro

Bone tissues were cultured for $48 \mathrm{hr}$ in a serum-free medium containing either vehicle of $\beta$-cryptoxanthin $\left(10^{-7}\right.$ or $\left.10^{-6} \mathrm{M}\right)$ in the presence or absence of cycloheximide $\left(10^{-6} \mathrm{M}\right)$. Each value represents the mean \pm S.E.M. of five experiments with separate rats. ${ }^{*} p<0.01$ compared with the control (none) value. White bars, control (vehicle); hatched bars, $\beta$-cryptoxanthin $\left(10^{-7} \mathrm{M}\right)$; black bars, $\beta$-cryptoxanthin $\left(10^{-6} \mathrm{M}\right)$.

induced by oral administration for 7 days at the lowest dose of $5 \mu \mathrm{g} / 100 \mathrm{~g}$ body weight, and the substance may also exert potent stimulation bone mass in these rats.

The presence of $\beta$-cryptoxanthin $\left(10^{-7}\right.$ or $\left.10^{-6} \mathrm{M}\right)$ in culture medium caused a significant increase in calcium content and alkaline phasphatase activity in the femoral-diaphyseal and-metaphyseal tissues obtained from aged female rats in vitro. This effect was abolished in the presence of cycloheximide, an inhibitor of protein synthesis, suggesting that newly synthesized protein components are needed for the anabolic effect of $\beta$-cryptoxanthin. The carotenoid may have a direct stimulatory effect on bone formation in the femoral tissues of aging rats. Meanwhile, it has been reported that the serum concentration of $\beta$-cryptoxanthin increases with the consumption of vegetable juice by women to the range of $1.3 \times 10^{-7}$ to $5.3 \times 10^{-7} \mathrm{M}^{28)}$ Presumably, $\beta$-cryptoxanthin has a physiologic role in stimulating bone components.

In conclusion, it has been demonstrated that the oral administration of $\beta$-cryptoxanthin induces an anabolic effect on bone components in the femoral tissues of aged female rats in vivo. Further studies are in progress to determine the preventive effect of this substance on osteoporosis. 


\section{REFERENCES}

1) Schapira, C., Slinn, S., Sarid, M., Mokadai, S., Kabara, A. and Silibermann, M. (1995) Calcium and vitamin $\mathrm{D}$ enriched diets increase and preserve vertebral mineral content in aging laboratory rats. Bone, 16, 575-582.

2) Wild, R. A., Buchamain, J. R., Meyers, C. and Demera, L. M. (1987) Declining adrenal androgen: an association with bone loss in aging women. Proc. Soc. Exp. Biol. Med., 186, 335-360.

3) Cooper, C. and Melton, J., III (1992) Epidemiology of osteoporosis. Trends Endocrinol. Metab., 3, 224 229.

4) Bonjour, J.-P., Schurch, M.-A. and Rizzori, R. (1996) Nutritional aspects of hip fractures. Bone, 18, 13951445.

5) Yamaguchi, M. (2002) Isoflavone and bone metabolism: Its cellular mechanism and preventive role in bone loss. J. Health Sci., 48, 209- 222.

6) Ono, R., Ma, Z. J. and Yamaguchi, M. (2000) Prolonged intake of fermented soybean diets with supplementation of isoflavone and saponin prevents bone loss in ovariectomized rats. J. Health Sci., 46, 70-74.

7) Ma, Z. J. and Yamaguchi, M. (2000) Synergistic effect of genistein and casein phosphopeptides on bone components in young and elderly female rats. $J$. Health Sci., 46, 474-479.

8) Ma, J. Z., Igarashi, A., Yamakawa, K. and Yamaguchi, M. (2001) Enhancing effect of zinc and vitamin $\mathrm{K}_{2}$ (menaquinone-7) on bone components in the femoral tissue of female elderly rats. J. Health Sci., 47, 40-45.

9) Yamaguchi, M., Hachiya, S., Hiratsuka, S. and Suzuki, T. (2001) Effect of marine algae extract on bone calcification in the femoral- metaphyseal tissues of rats: Anabolic effect of Sargassum horneri. J. Health Sci., 47, 533-538.

10) Uchiyama, S. and Yamaguchi, M. (2003) Preventive effect of Marine alga Sargassum horneri extract on bone loss in streptozotocin-diabetic rats in vivo. J. Health Sci., 49, 149-155.

11) Steinmetz, K. A. and Potter, J. D. (1996) Vegetable fruits, and cancer prevention: a review. J. Am. Diet. Assoc., 96, 1027-1033.

12) Forsyth, K. S., Watoson, R. R. and Gensler, H. L. (1989) Osteotoxicity after chronic dietary administration of 13-cis-retinoic acid, retinyl palmitate or selenium in mice exposed to tumor initiation and promotion. Life Sci., 45, 2149-2156.

13) Rohde, C. M., Manatt, M., Clagett-Dome, M. and DeLuca, H. F. (1999) Vitamin A antagonizes the action of vitamin D in rats. J. Nutr., 129, 2241-2250.
14) Promislow, J. H. E., Goodman-Gruen, D., Slymen, D. J. and Burret-Connor, E. (2002) Retinol intake and bone mineral density in the elderly: the Rancho Bernardo study. J. Bone Miner. Res., 17, 1349-1358.

15) Yamaguchi, M. and Uchiyama, S. (2003) Effect of carotenoid on calcium content and alkaline phosphatase activity in rat femoral tissues in vitro: The unique anabolic effect of $\beta$-cryptoxanthin. Biol. Pharm. Bull., 26, 1188-1191.

16) Yamaguchi, M. and Uchiyama, S. (2004) $\beta$-Cryptoxanthin stimulates bone formation and inhibits bone resorption in tissue culture in vitro. Mol. Cell. Biochem., 258, 137-144.

17) Uchiyama, S. and Yamaguchi, M. (2004) Inhibitory effect of $\beta$-cryptoxanthin on osteoclast-like cell formation in mouse marrow cultures. Biochem. Pharmacol., 67, 1297-1305.

18) Yamaguchi, M., Uchiyama, S. and Tsukamoto, Y. (2002) Stimulatory effect of menaquinone-7 on bone formation in elderly female rat femoral tissues in vitro: Prevention of bone deterioration with aging. Int. J. Mol. Med., 10, 729-733.

19) Yamaguchi, M., Oishi, H. and Suketa, Y. (1987) Stimulatory effect of zinc on bone formation in tissue culture. Biochem. Pharmacol., 36, 4007-4012.

20) Willis, J. B. (1960) Determination of calcium in blood serum by atomic absorption spectroscopy. Nature (London), 186, 249-250.

21) Taussky, H. H. and Shon, E. (1955) A microcolorimetric method for the determination of inorganic phosphorus. J. Biol. Chem., 202, 675-685.

22) Walter, K. and Schutt, C. (1965) Acid and alkaline phosphatase in serum. In Methods of Enzymatic Analysis (Bergmeyer, H. U., Ed.), Academic Press, New York, Vol. 1-2, pp. 856-860.

23) Lowry, O. H., Rosebrough, N. J., Farr, A. L. and Randall, R. J. (1951) Protein measurement with the Folin phenol reagent. J. Biol. Chem., 193, 265-273.

24) Flanagan, B. and Nichols, G. J. (1962) Metabolic studies of bone in vitro. VI. Collagen biosynthesis by surviving bone fragment in vitro. J. Biol. Chem., 237, 3686-3692.

25) Ceriotti, G. (1955) Determination of nucleic acids in animal tissues. J. Biol. Chem., 214, 39-77.

26) Majeska, R. J. and Wuthier, R. E. (1975) Studies on matrix vesicles isolated from chick epiphyseal cartilage. Association of pyrophosphatase and ATPase activities with alkaline phosphatase. Biochim. Biophys. Acta, 391, 51-60.

27) Canalis, E., Centrella, M., Burch, W. and McCarthy, T. L. (1989) Insulin-like growth factor-I mediates selective anabolic effects of parathyroid hormone in bone cultures. J. Clin. Invest., 83, 60-65.

28) McEligot, A. J., Rock, C. L., Shanks, T. G., Flatt, S. 
W., Newman, V., Faerber, S. and Pierce, P. (1995)

Comparison of serum cartenoid responses between women consuming vegetable juice and women consuming raw or cooked vegetables. Cancer Epidemiol. Biomarkers Prev., 4, 491-496. 